\title{
Communicating the Crisis: The European Commission on Social Media During the Economic Crisis in the European Union
}

\author{
Domagoj Bebić, Milica Vučković \\ Faculty of Political Science, University of Zagreb \\ Lepušićeva 6, Zagreb, Croatia \\ domagoj@edemokracija.hr, milica@edemokracija.hr \\ Marija Volarević \\ PhD student, Faculty of Social Sciences, University of Ljubljana \\ Kardeljeva pl. 5, Ljubljana, Slovenia \\ marija@edemokracija.hr
}

\section{Summary}

Looking at the official European Commission social media in the period of the economic crisis in Europe, the aim of this study is to test optimistic (Browning 2002, Coleman 2003; Hill \& Hughes 1998; Ward, Gibson \& Nixon 2003) and pessimistic (Kavanaugh 2002, Norris 2001) views about the role of the Internet in political communication. Relying on the optimistic ideas that social media can improve communication between representatives and the represented, we test to see if the European Commission used Facebook in order to improve communication with citizens. We use discourse analysis as a qualitative content analysis to look at status messages on the EC official Facebook page from 2010 until the end of 2012, focusing on which themes were encouraged by the EC and in which way did the EC communicate the crises to European citizens. Moreover, conducting a content analysis as a quantitative analysis we examine how often each theme was in the main focus of the status update.

Keywords: European Commission, social media, economic crisis

\section{Introduction}

In the first decade of the new millennium the world was faced with a new economic crisis. Starting in 2008 in only few months economic crisis defected all modern markets, including the European Union market too.

The role of the European Union and its institutions in resolving and communicating the crisis remained unclear. Some studies suggest that citizens were badly informed about the crisis and about the causes of the crisis. The Reuters Institute conducted extensive research on media coverage during the economic crisis in Europe. The study included 10 member states and more than ten thou- 
sand articles in 40 national newspapers published from 2010 to 2012. The data showed that in most of the examined member states, European institutions, including the European Commission, were perceived as ineffectual and confusing in addressing the crisis. Moreover, the data revealed that the European Union and its institutions were negatively perceived in the national print media of the examined countries during the period of crisis.

While we could argue that European institutions are maybe underrepresented and framed as a scapegoat in national media coverage, we wanted to test if they used alternative media channels to communicate about the crisis. We analysed the European Commission because one of the main goals of this institution is "communication" with the citizens of the European Union. Moreover, in 2010 the European Commission proposed a 10-year strategy named "Europe 2020" that, among other important issues, underlines seven flagships initiatives to catalyse progress under each priority theme ${ }^{1}$. One of the flagships was "a digital agenda for Europe" whose aim is to deliver sustainable economic and social benefits from a Digital Single Market, based on fast and ultra-fast Internet and interoperable applications, with broadband access for all by 2013, access for all to much higher Internet speeds (30 Mbps or above) by 2020 , and $50 \%$ or more of European households subscribing to Internet connections above $100 \mathrm{Mbp}^{2}$. This regulation showed that the Internet and its development is considered an important and needed tool. Yet, it is not clear how the European Commission itself uses the Internet to empower its role among the citizens and member states of the European Union.

In order to reveal if and how the European Commission used Internet during the economic crisis we analyse 285 Facebook status messages on the official European Commission Facebook page from June 2010, when the European Commission opened its official Facebook page, to the end of 2012, when the intensity of the crisis in most of the EU member states was in decline. Using qualitative analysis we revealed the main themes in focus in the European Commission's communication with European citizens. Using quantitative analysis we examined how often each theme was in the main focus.

This paper is divided into two main sections - a theoretical and then empirical section. In the theoretical part we discuss new methods and tools of political communication in the $21^{\text {st }}$ century with a focus on social media. In the empirical section we analyse the status updates of the European Commission during the economic crisis in Europe using both a qualitative and quantitative approach.

\footnotetext{
${ }^{1}$ Europe 2020 - 7 Flagship initiatives: (1) Innovation Union; (2) Youth on the move; (3) A digital agenda for Europe; (4) Resource efficient Europe; (5) An industrial policy for the globalization era; and (7) European platform against poverty
}

${ }^{2}$ Europe 2020 Flagship Initiative: "A Digital Agenda for Europe" 


\section{Theoretical part}

Many citizens believe that governments make decisions like private clubs, without the engagement of citizens who can no longer find any connection between the process of governing and their own elective vote (Hain, 2003). Furthermore, many authors believe that contemporary trends in the field of political media coverage, as well as trends in political communication, sometimes regarded as "spin democracy" stressing high inclusion of media logic in the political process, have resulted in a general distrust of political institutions, citizens' skepticism and disengagement (Entman, 1989; Hart, 1994; Cappella/Jamieson, 1997). Optimistic viewpoints about possible role of the Internet and new communication technologies in politics strongly underline how the Internet could solve these problems, strengthening ties between representatives and the represented, enabling two way communications with citizens in the role of strengthening democracy (Barber, 1984; Coleman, 2004; Grossman, 1995).

Yet, the question is whether citizens will renew their faith in the politics now when they have a platform where they can be equal with their representatives? Coleman thinks that ICTs can help through the creation of a more transparent, interactive government that is engaged in a wide dialogue with an interactive citizenry (2003). Street finds that the Internet may offer solutions for problems that obstruct political participation - "time, size, knowledge and access" (2001: 217). Chadwick suggests that political websites should provide infrastructure for deliberation and that political participation will follow (2006: 26). The rise of social media across Western democracies raises important questions for political scientists (Vaccari et. al, 2013: 2). How parties, politicians and crucial political institutions now use these new communication platforms, and how they directly engage with the audience and voters have become a new research area for scholars of political communication. In particular, it is assumed that social media may be conducive to greater political engagement in various ways: by providing information about political issues, by offering social cues that motivate citizens to take action, and by reducing the costs of collective action (ibid). After a long period of the mass media serving as a mediator between politicians and citizens, today, social media have created possibilities for direct communication and interaction, for citizens' engagement and political promotion.

The growing relevance of the Internet in everyday life, especially applications for social networking, such as Facebook, and micro-blogging sites, such as Twitter, is undisputed. The revolution of information communication technologies (ITC) in last decade have completely changed traditional forms of communication and mediation. With 511,483,906 citizens in European Union (EU28), the number of Internet users in the Union is 391,395,602 and the number of Facebook subscribers is $194,342,680^{3}$. Hence, in March 2015, the European Com-

\footnotetext{
${ }^{3}$ Internet World Stat, http://www.internetworldstats.com/europa.htm
} 
mission set out three main areas regarding the Internet: (1) Better access for consumers and businesses to digital goods and services; (2) Shaping the environment for digital networks and services to flourish, and (3) Creating a European Digital Economy and Society with long-term growth potential ${ }^{4}$.

In this chapter we have so far discussed the importance and possibilities of Internet, and specifically social media, in improving communication between representatives and the represented. In the next section we examine how the European Commission, as one of the executive bodies of the European Union uses Facebook to communicate with citizens. We chose to examine the European Commission's communication during the economic crisis in Europe as it is assumed that during the crisis communication should be more intense.

\section{Research design}

Since the purpose of this study is to detect the most common themes and subthemes of the European Commission's status messages on Facebook, as well as the main focus of each message, our approach is qualitative and quantitative.

The aim of inductive qualitative analysis is to conclude a general theory or concept from less general parts of the text (Thomas, 2006: 237). That is why we use this method to extract main themes and sub-themes from the status messages.

On the other hand, content analysis is a method for data collection, whose aim is an objective, systematic and quantitative description of the manifest content of communication (Berelson, 1952). With this method the aim is to gain insight into the incidence of certain themes and sub-issues as well as detecting the change of the themes throughout the years.

In order to reveal the trends and changes in issues that were in the focus of the European Commission's status messages on Facebook during the economic crisis we propose following research questions:

RQ1: Did European Commission recognize social media as an important channel in its communication with citizens?

RQ2: Did the European Commission communicate about the economic crisis with its citizens on its official Facebook page.

RQ3: What were the main topics of status messages on the official European Commission Facebook page?

We conducted an analysis on 285 status messages in the period from June 2010, when the EC opened its official fan page on Facebook, to the end of 2012. This time period is also the period in which all European countries were caught in the global economic crisis.

We divide the analysis into two parts. The first part involves an inductive qualitative approach where by analysing Facebook status messages we detect the

\footnotetext{
${ }^{4}$ Europe.eu: Digital Single Market Strategy: European Commission agrees areas for action (http://europa.eu/rapid/press-release_IP-15-4653_en.htm)
} 
main themes and sub-themes that the European Commission published on its Facebook page in examined time period. This gives us an overview of the key issues and topics that the EC, as an important body of European Union, published on its official channel. The second part involves quantifying the data in the detected content categories. The purpose of this part of research is to obtain information concerning the representation of a specific issue and to detect differences in referring to that certain issue during the time of crisis in Europe.

\section{Results and discussion}

The qualitative analyses detected seven main themes: economy, European Union policy, democracy, member states' policy, references to history, international relations, and specific personas that are highlighted in the status messages (Table1).

Table 1. Themes and Sub-themes of European Commission status messages

\begin{tabular}{|l|l|}
\hline THEMES & SUB-THEMES \\
\hline Economy & $\begin{array}{l}\text { Economic reconstruction; market economy; employment / } \\
\text { unemployment; economic crisis; green policy and sustainable } \\
\text { development }\end{array}$ \\
\hline European Union policy & $\begin{array}{l}\text { News form the Union; national development: European initiatives; } \\
\text { policy for youth; regular European policy; collaboration with other } \\
\text { European Union nations; the EU presidency; specific problems of } \\
\text { the Union }\end{array}$ \\
\hline Democracy & $\begin{array}{l}\text { Pluralism, human and minority rights; criminal, corruption and } \\
\text { nepotism; rule of law and justice }\end{array}$ \\
\hline $\begin{array}{l}\text { European Union member } \\
\text { states policy }\end{array}$ & $\begin{array}{l}\text { Specific initiatives; specific Member state problems; regional } \\
\text { relations }\end{array}$ \\
\hline $\begin{array}{l}\text { Reference to the countries } \\
\text { who are not member states of } \\
\text { the European Union }\end{array}$ & $\begin{array}{l}\text { Collaboration with the Union; accession countries; international } \\
\text { associations; the European crisis }\end{array}$ \\
\hline Reference to history & $\begin{array}{l}\text { EU history; certain parts EU history; history before the EU; } \\
\text { culture in the context of history }\end{array}$ \\
\hline $\begin{array}{l}\text { Reference to certain people in } \\
\text { the Union }\end{array}$ & Individuals from EU; individuals not from EU \\
\hline
\end{tabular}

Quantitative part of the study deals with the presence of certain issues in the EC's status messages. For each status we coded every sub-theme in order to reveal the frequency with which specific issues were mentioned. The data show that in the examined period the EC's official Facebook channel dealt with the theme of the economy in $7 \%$ of the examined status messages, while the crisis was mentioned 14 times in the examined time period. Furthermore, the crisis was mentioned in the context of providing solutions or information to overcome it. Yet, most of the time it was mentioned in the context of neglecting the seriousness of the issue and promoting certain EU initiatives (see Chart 1).

Issues concerning regular European Union policy were mentioned in most of the status messages. For instance, the news from the Union was mentioned in 84 
of the examined messages. News from the Union encompassed a summary of weekly news, information, new regulations, achievements, etc. During the examined time period the EC dealt with initiatives and EU policy in 67 and 34 of the examined status messages, respectively (Chart 2).

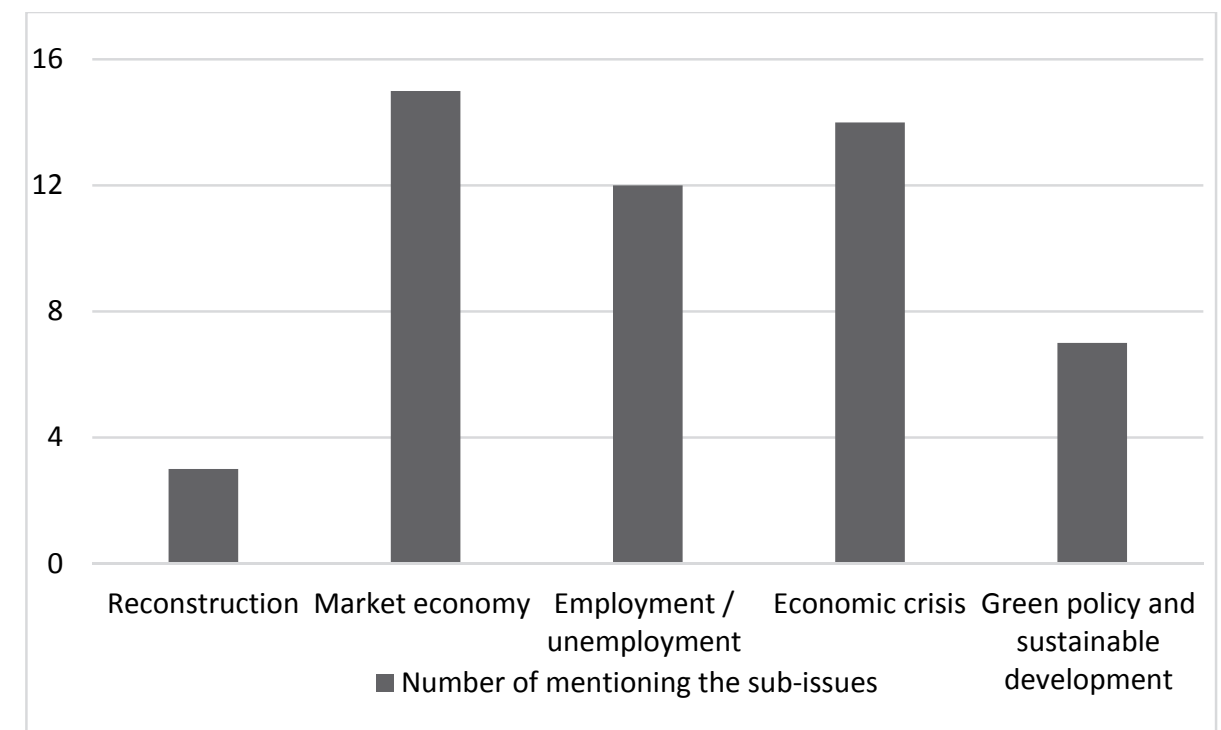

Chart 1 . The frequency of mentioning economy issues

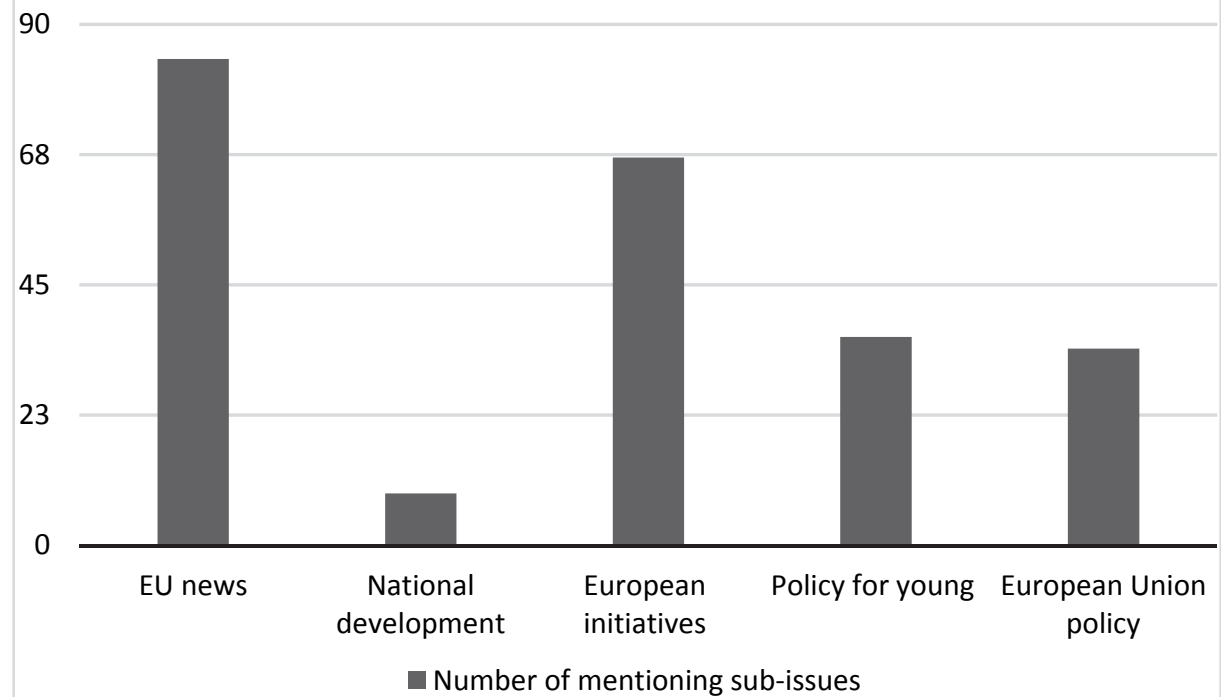

Chart 2: The frequency of mentioning regular EU policy issues; number of mentioning in Facebook status messages of European Commission 
In $7 \%$ of the examined status messages the European Commission dealt with the theme of democracy. Issues such as human rights in the Union - which encompass regular citizens' rights, rights for more specific social groups - children and woman especially, were mentioned in 24 of the messages.

The data show that the European Commission in the period of economic crisis usually used its Facebook account to promote and communicate its projects, plans and achievements. During the period of research a great number of the status messages highlighted the initiatives of the European Union or the specific interests of certain social groups. Furthermore, our research shows that the EC was eager to stimulate discussion and action of users, inviting them to view some material, to comment, answer questions or to do some offline action (to vote, to watch some material on other media, or to get involved in a project). As a result, in the examined time period more than eight thousand comments were posted on the EC's official Facebook fan page, there were more than 18 thousand Likes on the 285 examined status messages and 10,228 shares.

This research showed that the EC was silent and ignorant about the economic crisis on its official Facebook page. Furthermore, the results suggest that the EC's Facebook page was used as a promotional tool for activities, policies and initiatives.

On the other hand, as already mentioned, the ongoing Reuter's research shows that the crisis and the role of the European Commission was an important part of the print media's coverage of European Union in member states. While on the Facebook account the EC was silent about problems and difficulties of the economic crisis the theme of the crisis had a greater presence in the national print media of certain member states. The Reuters research looked at the period from 2010 to 2012. So far the research has observed that the crisis was an important theme in the national print media of each analysed member state. The conducted research reveals that the stories about the European Commission were mostly written in a form of a news story in the first ten pages of the newspaper and usually in the section of business or finance. In most of the analysed countries, European Union institutions, as well as the European Commission, were perceived as ineffectual and confused in addressing the crisis. The data show that the European Union and its institutions were perceived more negatively than positively in the national media during the time of crisis. The conducted Reuters analysis shows that in most member states the root of the crisis refers to political roots, the structure of the Euro system, as well as national fiscal and social policies. In most member states the responsibility for the crisis refers to the members of the Eurozone as a group.

Following, it remains unclear why the European Commission did not take advantage of social media as a more transparent and journalistically unmediated platform to communicate its position, role and specific actions concerning and dealing with the economic crisis. 


\section{Conclusion}

Due to its popularity and wide usage, social media has become an important and necessary tool in political communication. The main intention of this paper was to determine if the European Commission recognized Facebook as an important tool in connecting with citizens in the period of economic crisis in Europe. Our intention was to identify the main issues the $\mathrm{EC}$ presented in its status messages on its official Facebook page.

The research was conducted at two levels: first, a qualitative analysis of EC status messages identified the main themes and secondly, a quantitative analysis gave more specific insights into the presence of certain themes and sub-themes. Moreover, we examined the overall focus, technical details and response rate of the European Commission.

The Main themes we identified in the examined status messages during the economic crisis in European Union were the economy, European Union policy, democracy, and member states' policy, reference to history, international relations, and specific individuals. Our analyses showed that during the delicate period of crisis in the European Union, the European Commission mentioned economic crisis, which influenced the economy of entire Union, only 14 times on Facebook.

Our findings suggest that European Commission in general recognized Facebook only as a notice board while it did not recognize its Facebook page as an important platform for communicating with citizens. Bearing in mind that European institutions are often perceived as ineffectual and that their role remains vague and unknown to citizens, it is quite surprising that the EC did not use social media in a more communicative manner in order to clarify its role, policies and functions, especially during the economic crisis. Furthermore, social media is often a valuable source of information for journalists, which is why these findings are even more surprising.

Since the European Commission itself stresses the importance of the Internet and new communication platforms, as it is underlined in its strategic document Europe 2020, it remains to be seen if the European Commission will start using social media platforms more efficiently in the future. Moreover, a great number of citizens' comments, likes and shares on the status messages in the examined time period, suggest that citizens are willing to engage online if platform and content for engagement are provided. 


\section{References}

Barber, Benjamin R. Strong Democracy: Participatory Politics for a New Age. Berekly: University of California Press, 1984

Barnhurst, Kevin G. The New "Media Affect" and the Crisis of Representation for Political Communication. // International Journal of Press/Politics. 16 (2011), 4; 573-593

Borchardt, Klaus-Dieter. Abeceda prava Europske Unije. Luxemburg: Ured za publikacije Europske Unije, 2011

Ćapeta, Tamara; Rodin, Siniša. Osnove prava Europske Unije na temelju Lisabonskog ugovora. Zagreb: Narodne novine, 2011

Cappella, Joseph N.; Jamieson, Kathleen Hall. Spiral of Cynicism : The Press and the Public Good. Pennsylvania: Oxford University Press, 1997

Chadwick, Andrew. Internet Politics: States, Citizens and New Communication Technologies. New York: Oxford University Press, 2006

Coleman, Stephen. Explorning New Media Effects on Representative Democracy. // Journal of Legislative Studies. 9 (2003), 3; 1-6

Coleman, Stephen. Explorning New Media Effects on Representative Democracy. // Journal of Legislative study. 9 (2004), 3; 1-16

Entman, Robert M. Democracy Without Citizens: Media and the Decay of American Politics. New York: Oxford University Press, 1989.

European Commission. Economic Crisis in Europe: Causes, Consequences and Responses. Luxembourg: European Economy 7, 2009.

Gibson, Rachel Kay; Nixon, Paul; Ward, Stephen. Political parties and the Internet: net gain? London: Routledge, 2003

Grossman, Lawrence K. The electronic republic. New York : Viking, Penguin, 1995

Hain, Peter. Why Bigger is Better: Enlargement and the Future of Europe. // New Economy. 10 (2003), 2; 95-100

Hart, Roderick. Seducing America: How Television Charms the American Voter. New York: Oxford University Press, 1994

Hill, Kevin A.; Hughes, John E. Cyberpolitics: Citizen Activism in the Age of the Internet. Lanham: Rowman \& Littlefield Publishers, 1998

Kaldor, Mary; Selchow, Sabine; Deel, Sean; Murray-Leach, Tamsin. The ‘bubbling up' of subterranean politics in Europe. London: London School of Economics and Political Science, Civil Society and Human Security Research Unit, 2012

Kavanaugh, Andrea; Patterson, Scott. The impact of community computer networks on social capital and community involvement. // American Behavioral Scientist. 45 (2001), 3; 496-509

Murray-Leach, Tamsin; Kouki, Hara; Mattes, Daniel; Mollenkamp, Daniel; Radice, Henry; Saltman, Erin Marie; Secondo, Donata; Sommer, Moritz. Crisis Discourses in Europe Media EU-phemisms and Alternative Narratives. London: London School of Economics and Political Science, Civil Society and Human Security Research Unit, 2014

Musiałkowska, Ida; Sapała, Magdalena; Wróblewski, Łukasz. The strengthening of the Single European Market vs. the crisis. // Poznań University of Economics. 12 (2012), 2; 74-105

Norris, Pippa. Political Communications and Democratic Politics, pp. 163-180 in Bartle, John and Griffiths, Dylan (eds) Political Communication Transformed: From Morrison to Mandelson. Basingstoke: Palgrave, 2001

Peter Dahlgren. The Internet, Public Spheres, and Political Communication: Dispersion and Deliberation. // Political Communication. 22 (2005), 2; 147-162

Savigny, Heather. Public Opinion, Political Communication and the Internet // Political science association, University of Birmingham. 22 (2002), 1; 1-8

Street, John. Mass Media, Politics and Democracy. London: Palgrave Macmillan, 2001

Vaccari, Cristian; Valeriani, Augusto; Barberá, Pablo; Bonneau, Richard; Jost, John T.; Nagler, Jonathan; Tucker, Joshua. Social media and political communication. A survey of Twitter us- 
ers during the 2013 Italian general election. // Rivista italiana di scienza politica. 43 (2013), 3; $381-410$

Wille, Anchrit. The politicization of the EU Commission: democratic control and the dynamics of executive selection. // International Review of Administrative Sciences. 78 (2012), 3; 383402

Wojcieszak, Magdalena. Transnational Connections Symposium: Challenges and Opportunities for Political Communication Research. // International Journal of Communication. 6(2012); 255265

Content Analysis Dataset, The Euro Crisis, Media Coverage, and Perceptions of Europe within the EU Project, Reuters Institute for the Study of Journalism, University of Oxfordm (2015): $\mathrm{http}: / /$ reutersinstitute.politics.ox.ac.uk/publication/euro-crisis-media-coverage-andperceptions-europe-within-eu (Access date:15.4.2015.)

Europa.eu (2010): http://europa.eu/about-eu/institutions-bodies/european-commission/index_en. htm (Access date: 09.03.2015.)

Europe 2020. A strategy for smart, sustainable and inclusive growth, European Commission, COM (2010): http://eur-lex.europa.eu/LexUriServ/LexUriServ.do?uri=COM:2010:2020:FIN: EN:PDF. (Access date: 15.3.2015)

Making sense of the impact of social media on crisis communication (2013): http://www.prconversations.com/index.php/2013/11/making-sense-of-the-impact-of-socialmedia-on-crisis-communication/ (Access date: 15.03.2015.)

The Euro Crisis in the Press : The Politics of Public Discourse in Europe - LSE blog (2015): http://blogs. lse.ac.uk/eurocrisispress/about/ (Access date: 27.04.2015.)

The European Parliament LGBT rights (2010): http://www.lgbt-ep.eu/work/priority-2/ (Access date: 09.03. 2015.) 